\title{
Application of a tunnel-ventilated barn on the physiological responses, milk yield, and dry matter intake of dairy cows in tropical area during the wet season
}

\author{
Aan Andri Yano - Adiarto - Diah Tri Widayati
}

Yano AA (Corresponding author) - Adiarto

Department of Animal Production, Faculty of Animal Science, Universitas Gadjah Mada, Yogyakarta, Indonesia. email: a.andri@mail.ugm.ac.id

\author{
Widayati DT \\ Department of Animal Breeding and Reproduction, Faculty of \\ Animal Science, Universitas Gadjah Mada, Yogyakarta, \\ Indonesia.
}

Received: March 28, 2018 • Revised: May 29, 2018 • Accepted: May 29, 2018

\begin{abstract}
Dairy cows often experience heat stress in the tropics. Tunnel ventilation technology reduces heat stress in dairy cow housing. Here, we examined the performance of tunnel-ventilated barns on the physiological responses, milk yield, and dry matter intake of dairy cows during the wet season in a tropical area. The experiment was conducted on a commercial dairy farm in Malang, Indonesia from mid December 2017 until mid January 2018. Lactating Friesian Holstein cows $(n=661)$ were studied in two barns of different dimension, with cooling treatments. Air temperature, relative humidity, and air speed were measured. Respiration rate, lying down percentage, milk yield, and dry matter intake were analyzed in response to modified environmental conditions. Data were analyzed with independent sample $t$ tests using SPSS $^{\circledR}$ Statistics 24 for Windows. Outisde and inside air speeds for both barns $(\mathrm{P}<0.05)$ showed significant difference. Surprisingly, no differences were found for temperature (T), relative humidity (RH), and temperature-humidity index (THI) between the outside and inside for both barns ( $\mathrm{P}>0.05)$. A significant difference was noted in milk yield, dry matter intake (DMI), respiration rate (RR), and lying down percentage (LDP) $(\mathrm{P}<0.05)$. Thus, the tunnel-ventilated barn performed better and air speed was better distributed inside the barn. However, the barn had environmental conditions similar to those outside. Dairy cows showed high RR as milk yield and DMI increased. In the future, lying down behavior of dairy cows in response to cooling treatments in the tropics needs to be further studied.
\end{abstract}

Keywords: dairy housing, heat stress, tropical environment

\section{Introduction}

High temperature and air humidity are the main constraints for maintaining dairy cows in tropical areas (Gantner et al 2011; Palulungan et al 2013). Typically, temperature $(\mathrm{T})$ and relative humidity $(\mathrm{RH})$ in tropical areas range from 24 to $34^{\circ} \mathrm{C}$ and 60 to $90 \%$, respectively. However, the dairy cow thermoneutral zone ranges from 13 to $25^{\circ} \mathrm{C}$. In a tropical environment, even in the wet season, dairy cows still potentially experience continuous heat stress resulting in decreased productivity (Yani and Purwanto 2006).

The temperature-humidity index (THI) is widely used to indicate cow heat stress but is designed for a dry environment (Armstrong 1994; Ravagnolo et al 2000). Milk production decreased by $0.32 \mathrm{~kg}$ per unit of THI increase (West 2003) and by $0.2 \mathrm{~kg}$ per unit THI when THI exceeded 72 (Ravagnolo et al 2000). Additionally, air speed and solar radiation and their interactions are environmental contributors of heat stress (West 2003). Physical modification of the environment can reduce the effects of thermal stress (Beede and Collier 1986); shading, housing, and fans are techniques used to alleviate the impacts of heat stress on dairy cattle (Panjono et al 2009).

Tunnel ventilation technology facilitates the reduction of heat stress for housed dairy cows (Smith et al 2006a). Tunnel ventilation systems are designed to achieve a specific air speed to optimize convective heat loss by placing a bank of fans at one end of the building with inlets at the opposite end (Shiao et al 2011). Previous studies have reported that cows produced $3 \%$ more milk at the tunnel-ventilated barn than in a conventional free-stall barn in a subtropical area (Shiao et al 2011). There was also an increase in milk yield over a 10 week trial by $2.8 \pm 0.19 \mathrm{~kg} / \mathrm{cow}$ day $^{-1}$ in a temperate zone (Smith et al 2006b). This study examined the effects of tunnel-ventilated barn on the physiological responses, milk yield, and dry matter intake of dairy cows during the wet season of a tropical area. We hypothesized that there would be a difference in milk yield, dry matter intake (DMI), and physiological responses between the two barns and between temperature $(\mathrm{T})$, relative humidity $(\mathrm{RH})$, and air speed outside and inside the barn. 


\section{Materials and Methods}

The experiment was conducted on a commercial dairy farm in Malang (latitude $07^{\circ} 46^{\prime} 48^{\prime \prime}-08^{\circ} 46^{\prime} 42^{\prime \prime} \mathrm{S}$ and longitude $112^{\circ} 31^{\prime} 42^{\prime \prime}-112^{\circ} 48^{\prime} 48^{\prime \prime} \mathrm{E}$ ), Indonesia from mid December 2017 until mid January 2018 during wet season. The rainfall average from December until January was $268 \mathrm{~mm}$ (Badan Pusat Statistik (BPS), Central Bureau of Statistics Indonesia 2017). The wet season is categorized by rainfall exceeding 100 $\mathrm{mm}$ in one month (As-syakur 2008).

A total of two barn cooling treatments were established. The control barn (BC) had a maximum roof height of $4.85 \mathrm{~m}$, side eaves of $3.65 \mathrm{~m}$, and a total area of $154 \mathrm{~m} \times 30$ $\mathrm{m}$. The treatment barn (BT) had a maximum roof height of 8.3 $\mathrm{m}$, side eaves of $4.9 \mathrm{~m}$, and a total area of $158 \mathrm{~m} \times 30 \mathrm{~m}$. Both barns were open at the front. A total of 31 (BC) and 46 (BT) exhaust fans ( 15 horse power, $1.4 \mathrm{~m}$ diameter, 3 blades), were placed at the back of each barn, and were operated for $24 \mathrm{~h} / \mathrm{d}$ and were covered by a segmental plastic curtain. The pen floors were made of iron segmental lining for pen and the alley was made of concrete. A light was turned on for $12 \mathrm{~h}$ during the night. The cow allocation area $(117.3 \mathrm{~m}$ long $\times 4.6 \mathrm{~m}$ wide for BC; $120 \mathrm{~m}$ long $\times 4.6 \mathrm{~m}$ wide for BT) was horizontally divided into 2 equal-sized pens in each barn (pen A and B). The space between the two pens was $4.9 \mathrm{~m}$ long $\times 4.6 \mathrm{~m}$ wide. All of the facilities, including the stalls, water and salt trough, headlock, and the floor plan of the two experimental barns were similar.

All animal use protocols for the exploratory research was reviewed and approved by the commercial dairy farm. A total of 661 lactating Friesian Holstein (FH) cows were divided in 2 groups based on their days in milk (DIM). Their average condition before the trial but during the wet season was $11.2 \pm 0.83$ for pen A of the BC barn, $42.6 \pm 2.88$ for pen $\mathrm{B}$ of the BC barn, 105.8 \pm 1.92 for pen A of the BT barn, and $114.6 \pm 4.56$ for pen B of the BT barn. Every day, cows were moved from other barns (first-lactation cow) to the BC, the BT and other barns based on DIM. Cow population constantly changed in the barn pens because of the different DIM. Thus, to calculate the results, cow sample size was determined by using the smallest population during the research period.

During the 31 day trial period, sample data were taken every 2 days, and barn T, RH, and air speed were measured every $3 \mathrm{~h}$ for $24 \mathrm{~h}$ both inside and outside of each barn. T and RH were measured using 6 hygrothermographs (Xuzhou Sanhe Automatic Control Equipment Co., Ltd., China) that were consistently spaced in 3 locations above the headlock and stall positions, $2.5 \mathrm{~m}$ above the ground in each barn. The outside $\mathrm{T}$ and $\mathrm{RH}$ were measured at the south and north points of each barn. To plot the diurnal changes and to calculate THI, temperature and $\mathrm{RH}$ for each barn was first averaged by time and the number of data points and was then averaged across the number of days [THI $=9 / 5 \times \mathrm{T}+32-0.55 \times(1-\mathrm{RH}) \times$
(9/5 $\times \mathrm{T}-26)$, with $\mathrm{T}$ in ${ }^{\circ} \mathrm{C}$ and $\mathrm{RH}$ in percent] (NOAA 1976). In this study, THI was categorized based on Hahn et al (2009). Air speed measurements were collected similar to $\mathrm{T}$ and $\mathrm{RH}$ using Lutron LM-8000A (ISO 9001 Quality Management System Certified by SGS).

During the experiment, individual cow respiration rate (RR) was counted five times during a $24 \mathrm{~h}$ period since cows were inside the barns at 0300, 0900, 1200, 1800, and 2100. Respiration rate was measured by flank movement per minute and was counted for 15 s (Ortiz et al 2015). Lying down percentage (LDP) was measured similar by first counting the number of standing cows then the number of eating and drinking cows. To calculate the number of lying down cows, the number of standing cows and eating and drinking cows were subtracted from the total number of cows. The LDP was calculated by dividing the number of lying down cows with the number of standing and lying down cows (excluding the eating and drinking cows) and then multiplying the quotient by 100 to calculate the percentage.

$\mathrm{LDP}=$

lying down cows

$\overline{\text { laying down cows }+(\text { standing cows-eating and drinking cows })} \times 100 \%$

The measurement of other physiological responses, including heart rate, rectal temperature, and pulse rate, were prohibited by the management board of the commercial dairy industry to avoid animal discomfort.

Feed samples for lactating cows were collected at 3 different locations (the front, middle, and rear of the feed line) of the BC and BT barns and were then mixed thoroughly before undergoing $48 \mathrm{~h}$ of drying at $55^{\circ} \mathrm{C}$. Dried feed samples were pooled, ground, and analyzed. The cows were fed a total mixed ration (TMR) ad libitum on the feed line and were allowed continuous access to water. The TMR was composed of alfalfa hay and concentrate. The mean chemical composition of the TMR was $11.89 \mathrm{Mcal}$ of $\mathrm{NE}_{\mathrm{L}} / \mathrm{kg}, 16.29 \%$ crude protein and $5.17 \%$ crude fat (DM basis).

The amount of TMR offered, next-day refusals, and the actual number of cows in each group were recorded daily. Fresh TMR and next-day refusals were sampled daily for two weeks from the 0 -d trial date to determine the dry matter intake (DMI) measurement per pen. Cows were milked thrice daily at 0600, 1400, and 2200. Individual milk yields were recorded on a daily basis and were averaged by pen.

Relative environmental measures were expressed as the mean \pm standard mean error. Bovine data, including RR, LDP, milk yield, and DMI were analyzed by each group. Data were analyzed using IBM ${ }^{\circledR}$ SPSS Statistics 24.0 for Windows. Independent sample $t$ tests were used to compare the cooling effect between the two barns at a significance level of $\mathrm{P}<0.05$. If the P-value was close to 0.01 , the presence of a tendency was noted. 


\section{Results}

There was a significant difference in the air speed between the outside and inside for both barns $(\mathrm{P}<0.05)$. However, no differences were found for T, RH, and THI between outside and inside for both barns $(\mathrm{P}>0.05)$ (Table 1).
For this study, the cows were only out of the barn for milking. Thus, we compared LDP and RR of the cows for the $\mathrm{BC}$ and the BT barns. There was a significant difference in milk yield, DMI, RR, and LDP $(\mathrm{P}<0.05)$.

Table 1 Mean values of environmental conditions of the tunnel-ventilated barn for $24 \mathrm{~h}$.

\begin{tabular}{|c|c|c|c|c|c|c|c|c|c|c|c|c|c|}
\hline \multirow{2}{*}{ BC Barn } & & \multicolumn{9}{|c|}{ Time (h) } & \multirow{2}{*}{ Mean } & \multirow{2}{*}{ SEM \pm} & \multirow{2}{*}{$\begin{array}{c}\mathrm{P} \\
\text { value }\end{array}$} \\
\hline & & 0000 & 0300 & 0600 & 0900 & 1200 & 1500 & 1800 & 2100 & 2400 & & & \\
\hline \multirow{4}{*}{$\begin{array}{l}\text { Temperature } \\
\left({ }^{\circ} \mathrm{C}\right) \\
\text { Relative } \\
\text { humidity }(\%)\end{array}$} & In & 20.14 & 19.27 & 20.06 & 22.91 & 23.81 & 22.14 & 20.72 & 19.99 & 20.15 & 21.26 & 0.18 & \multirow{2}{*}{$0.07^{\mathrm{ns}}$} \\
\hline & Out & 20.09 & 19.50 & 20.4 & 25.61 & 26.40 & 22.14 & 20.80 & 20.40 & 20.10 & & 0.30 & \\
\hline & In & 87.60 & 89.33 & 88.89 & 83.72 & 83.78 & 89.94 & 93.72 & 88.61 & 87.83 & 85.64 & 1.33 & \multirow{2}{*}{$0.80^{\mathrm{ns}}$} \\
\hline & Out & 89.21 & 89.30 & 88.00 & 83.30 & 76.90 & 84.90 & 92.70 & 84.60 & 89.20 & 86.10 & 1.24 & \\
\hline \multirow[b]{2}{*}{ THI } & In & 67.30 & 66.29 & 67.55 & 71.83 & 73.32 & 70.99 & 68.88 & 67.36 & 67.36 & 69.41 & 0.32 & \multirow[b]{2}{*}{$0.13^{\text {ns }}$} \\
\hline & Out & 67.41 & 66.50 & 68.10 & 76.16 & 76.70 & 70.54 & 68.90 & 67.80 & 67.50 & 70.27 & 0.46 & \\
\hline \multirow{2}{*}{$\begin{array}{l}\text { Air speed } \\
(\mathrm{m} / \mathrm{s})\end{array}$} & In & 2.39 & 2.65 & 2.87 & 2.38 & 2.19 & 2.26 & 2.20 & 2.18 & 2.65 & 2.56 & 0.06 & \multirow{2}{*}{$0.00 *$} \\
\hline & Out & 1.01 & 0.48 & 0.68 & 1.89 & 2.45 & 1.75 & 1.28 & 1.51 & 1.65 & 1.46 & 0.16 & \\
\hline
\end{tabular}

BT Barn

\begin{tabular}{llllllllllllll}
\hline Temperature & In & 19.90 & 19.71 & 20.51 & 23.48 & 24.22 & 21.95 & 20.71 & 20.26 & 19.98 & 21.67 & 0.21 & \multirow{2}{*}{$0.87^{\text {ns }}$} \\
$\left({ }^{\circ} \mathrm{C}\right)$ & Out & 20.08 & 19.50 & 20.50 & 24.83 & 25.00 & 22.25 & 20.60 & 20.40 & 20.10 & 21.62 & 0.25 & \\
Relative & In & 89.20 & 92.06 & 87.72 & 83.56 & 79.72 & 91.67 & 94.77 & 89.72 & 89.27 & 85.76 & 1.25 & $0.79^{\text {ns }}$ \\
humidity $(\%)$ & Out & 88.65 & 92.60 & 91.17 & 79.80 & 72.80 & 84.40 & 93.10 & 87.30 & 88.70 & 86.22 & 1.30 & \\
& In & 67.31 & 67.13 & 68.16 & 72.77 & 73.59 & 70.82 & 68.91 & 67.90 & 67.40 & 69.71 & 0.33 & $0.88^{\text {ns }}$ \\
THI & Out & 67.80 & 66.70 & 68.30 & 74.57 & 74.10 & 70.73 & 68.50 & 67.90 & 67.50 & 69.79 & 0.37 & \\
Air speed & In & 3.00 & 2.91 & 3.07 & 3.13 & 2.45 & 2.85 & 2.42 & 2.86 & 3.21 & 2.83 & 0.07 & $0.00^{*}$ \\
(m/s) & Out & 0.58 & 0.68 & 0.87 & 1.88 & 2.37 & 1.65 & 1.53 & 1.34 & 2.13 & 1.55 & 0.16 &
\end{tabular}

Table 2 Mean values of physiological responses of lactating dairy cows.

\begin{tabular}{llllllllll}
\hline \multirow{2}{*}{ Variable } & \multirow{2}{*}{ Barn } & \multicolumn{9}{c}{ Time $(\mathrm{h})$} & \multirow{2}{*}{ Mean } & \multirow{2}{*}{ SEM \pm} & P \\
\cline { 3 - 7 } & & 0300 & 0900 & 1200 & 1800 & 2100 & & \\
\hline Lay down percentage & BC & 84.99 & 88.59 & 72.09 & 70.78 & 83.60 & 80.00 & 0.01 & \multirow{2}{*}{$0.00^{*}$} \\
(\%) & BT & 83.23 & 91.56 & 80.27 & 85.53 & 90.20 & 86.20 & 0.01 & \\
Respiration rate & BC & 39.50 & 44.93 & 41.15 & 45.22 & 38.41 & 41.84 & 0.65 & $0.00 *$ \\
(times/min) & BT & 45.34 & 44.59 & 45.15 & 42.00 & 49.78 & 45.38 & 0.59 & \\
\hline
\end{tabular}

Table 3 Mean of milk yield and DMI sampling of lactating dairy cows.

\begin{tabular}{|c|c|c|c|c|c|c|c|c|c|c|}
\hline \multirow{2}{*}{ Variable } & \multirow{2}{*}{ Barn } & \multicolumn{6}{|c|}{ Day sampling } & \multirow{2}{*}{ Mean } & \multirow{2}{*}{ SEM \pm} & \multirow{2}{*}{$\begin{array}{c}\mathrm{P} \\
\text { value }\end{array}$} \\
\hline & & 1 & 3 & 5 & 8 & 10 & 12 & & & \\
\hline \multirow{2}{*}{ Milk yield (kg/d) } & $\mathrm{BC}$ & 18.99 & 22.03 & 25.50 & 24.77 & 23.12 & 22.55 & 21.87 & 0.96 & \multirow{2}{*}{$0.00^{*}$} \\
\hline & BT & 38.67 & 39.26 & 38.82 & 37.71 & 39.19 & 39.15 & 38.85 & 0.26 & \\
\hline \multirow{2}{*}{ DMI (kg/cow/d) } & $\mathrm{BC}$ & 20.05 & 22.00 & 21.95 & 20.85 & 23.35 & 22.61 & 21.70 & 0.97 & \multirow{2}{*}{$0.00^{*}$} \\
\hline & BT & 26.40 & 27.80 & 26.70 & 26.95 & 25.65 & 27.26 & 26.59 & 0.19 & \\
\hline
\end{tabular}

*Significant at $\mathrm{P}<0.05 ;$ ns: non-significant at $\mathrm{P}>0.05$

\section{Discussion}

There were consistent results for both barns (Table 1). Surprisingly, environmental modifications did not lead to a decrease in ambient temperature or an increase in the relative humidity even though there were a number of fans in the barns. THI in the tunnel-ventilated barn did not decrease when compared to outside conditions. Suadsong et al (2008) reported high $\mathrm{T}$ and $\mathrm{THI}$ both outside and inside the barns in a tropical area $\left(31.4^{\circ} \mathrm{C}, 83.1\right.$ outside and $26.5^{\circ} \mathrm{C}, 78$ inside, respectively). Inside $\mathrm{RH}$ was relatively similar to the outside (74.6\%); however, outside RH was lower $(86.5 \%)$ than our findings (Table 1). The thermoneutral zone for dairy cows has a wide range: $13-18^{\circ} \mathrm{C}$ (McDowell 1972); $4-25^{\circ} \mathrm{C}$ (Yousef 1985); and 5-25 ${ }^{\circ} \mathrm{C}$ (Jones and Stallings 1999).

The findings of the current study are consistent with those of Ruakura and Roads (2015) where ventilation provides the uniform distribution of air. In this study, the air speed in 
both barns was relatively similar during the study and ranged from 2.18 to $3.21 \mathrm{~m} / \mathrm{s}$. Shiao et al (2011) found that wind speed inside the tunnel-ventilated barn ranged from 1.23 to $2.06 \mathrm{~m} / \mathrm{s}$, which is lower than the results of our current study.

The THI in the tunnel-ventilated barn and outside of both barns exceeded the critical point of 72 at 1200 inside and outside both barns, suggesting that the cows were exposed to conditions conducive to heat stress for $3 \mathrm{~h}$ until 1500 . Additionally, the cows were moved from inside the barn to the milking parlor at 1400 , which continued the exposure to conditions that contribute to heat stress. However, sprinklers are provided by the commercial dairy industry for loading areas and for some locations on the path to the loading area. Sprinklers are used to alleviate the impact of heat stress on dairy cattle (Chan et al 1997). Shiao et al (2011) reported that using a sprinkler cooling system significantly increased the potential efficacy and feasibility of tunnel-ventilated barns for alleviating cow heat stress in hot and humid areas.

Cow milk yield in the BT barn was higher than that in the BC barn. High milk yield reflects the high availability of energy to produce milk (Gwayumba et al 2002). These results indicate that high milk may be due to higher DMI in the BT barn. It has been shown that increased DMI increases milk yield (Puggaard et al 2014). Smith et al (2006b) showed an $11 \%$ increase of DMI can increase milk yield to $2 \mathrm{~kg}$ of milk/cow day ${ }^{-1}$. However, higher milk yield increased internal body heat (Wang et al 2018). Therefore, it is not surprising that cows in the BT barn had higher RR than those in BC barn; heat dissipation was expressed through higher RR. Additionally, heat accumulation was also influenced by the $\mathrm{T}$ inside the barn.

The $\mathrm{T}$ inside of the BT barn was slightly higher than that of the BC barn. Hahn et al (1997) showed that T was positively correlated with RR. Shiao et al (2011) reported RRs (42-53 times/min) similar to the present findings (Table 2). Increased $\mathrm{RR}$ in cows happens when the ambient $\mathrm{T}$ reaches $19^{\circ} \mathrm{C}$ and sweating commences at $25^{\circ} \mathrm{C}$ (Maia et al 2005ab). At 1200 , the outside $\mathrm{T}$ reached $26.40^{\circ} \mathrm{C}$ (BC barn) and $25^{\circ} \mathrm{C}$ (BT barn), suggesting that dairy cows started to sweat when they were milked at 1400. Astuti and Sudarman (2015) suggested that increased RR was due to high humidity (greater than $78 \%$ relative humidity); RH in this study was reported greater than $78 \%$. However, recommended RR for cow ranges between 26 and 35 times per min (Reece 1993).

Cow LDP in the BT barn was higher than the cows in the BC barn. Herbut and Angrecka (2018) reported that lying down behavior decreased when THI started to increase. However, since lying down behavior was only exhibited when the cows were inside the barn, our study cannot validate the findings of the previous research due to similar THI for both barns. Furthermore, this study is limited by the lack of information on lying times.
The tunnel-ventilated barn performed better and air speed was better distributed inside the barn in this tropical area. However, the barn showed similar air T, RH, and THI as the outside environmental conditions. Dairy cows had higher higher RRs with increased milk yield and DMI. The effects of a tunnel-ventilated cooling system on dairy cow lying down behavior in the tropics need more examination in future studies.

\section{Acknowledgements}

The authors would like to express our sincere thanks to Indonesia Endowment Fund for Education for providing financial support for the research under grant 20160711037569.

\section{References}

Armstrong DV (1994) Heat stress interaction with shade and cooling. Journal of Dairy Science 77:2044-2050.

As-Syakur A (2008) Evaluasi zonaagroklimat dari klasifikasi schimidt-ferguson menggunakan aplikasi sistem informasi geografi (SIG). Journal Pijar 3: 17-22.

Astuti DA, Sudarman A (2015) Physiological status, blood profile and body composition of sheep fed with ca-saponified lemuru oil coated by herbs. Bulletin of Animal Science 39:116-122.

Beede DK, Coolier RJ (1986) Potential nutricions for intensive managed cattle during thermal stress. Journal of Dairy Science 62:543-550.

BPS. Agricultural Statistic based on Census 2017. https://www.bps.go.id/linkTableDinamis/view/id/1016: BPS; 2017.

Chan SC, Huber JT, Chen KH, Simas JM, Wu Z (1997) Effect of ruminally inert fat and evaporative cooling on dairy cows in hot environmental temperatures. Journal of Dairy Science 80:11721178 .

Gantner VP, Mijic P, Kuterovac K, Solic D, Gantner R (2011) Temperature-humidity index values and their significance on the daily production of dairy cattle. Mljekarstvo 61:56-63.

Gwayumba W, Christensen DA,McKinnon JJ, Yu P (2002) Dry matter intake, digestibility and milk yield by friesian cows fed two napier grass varieties. Asian-Australasian Journal of Animal Science 15: 516-521.

Hahn GL, Gaughan JB, Mader TL, Eigenberg RA (2009) Thermal indices and their application for livestock environments. In: DeShazer JA (ed) Livestock Energetics and Thermal Environmental Management ASAE, St. Joseph, MI, pp 113-130.

Hahn GL, Parkhurst AM, Gaughan JB (1997) Cattle respiration rate as a function of ambient temperature. ASAE, St. Joseph, MI, Paper\# MC97-121.

Herbut P, Angrecka S (2018) Relationship between THI level and dairy cows behaviour during summer period. Italian Journal of Animal Science 17:226-233.

Jones GM, Stallings CC (1999) Reducing heat stress for dairy cattle. Virginia Cooperative Extension, Virginia.

Maia ASC, daSilva RG, Loureiro CMB (2005a) Respiratory heat loss of Holstein cows in a tropical environment. International Journal of Biometeorology 49:332-336. 
Maia ASC, daSilva RG, Loureiro CMB (2005b) Sensible and latent heat loss from the body surface of Holstein cows in a tropical environment. International Journal of Biometeorology 50:17-22.

McDowell RE (1972) Improvement of Livestock Production in Warm Climate. WH Freeman and Co, San Frascisco.

NOAA (1976) Livestock hot weather stress. In: Operations Manual Letter C31-76. NOAA, Kansas.

Ortiz XA, Smith JF, Rojano F, Choi CY, Bruer J, Steele T, Schuring N, Allen J, Collier RJ (2015) Evaluation of conductive cooling of lactating dairy cows under controlled environmental conditions. Journal of Dairy Science 98:1759-1771.

Palulungan JA, Adiarto, Hartatik T (2013) Pengaruh kombinasi pengkabutan dan kipas angin terhadap kondisifisiologis sapi perah peranakan Friesian holland. Bulletin of Animal Science 37: 189-197.

Panjono, Widyobroto BP, Suhartanto B, Baliarti E (2009) Pengaruh penjemuran terhadap kenyamanan dan kinerja produksi sapi peranakan ongole. Bulletin of Animal Science 33:17-22.

Puggaard L, Lund P, Liesegang A, Sehested J (2014) Long term effect of reduced dietary phosphorus on feed intake and milk yield in dry and lactating dairy cows. Livestock Science 159:18-28.

Ravagnolo O, Misztal I, Hoogenboom G (2000) Genetic component of heat stress in dairy cattle, development of heat index function. Journal of Dairy Science 83:2120-2125.

Reece WO (1993) Respiration in mammals. 11edn. Cornell University Press, New York.

Ruakura C, Roads M (2015) Dairy cow housing: A good practice guide for dairy housing in New Zealand. DairyNZ Limited, New Zealand.

Shiao TF, Chen JC, Yang DW, Lee SN, Lee CF, Cheng WTK (2011) Feasibility assessment of a tunnel-ventilated, water-padded barn on alleviation of heat stress for lactating holstein cows in a humid area. Journal of Dairy Science 94:5393-5404.

Smith T R, Chapa A, Willard S, Herndon Jr C, Williams RJ, Crouch J, Riley T, Pogue D (2006a) Evaporative tunnel cooling of dairy cows in the southeast I: Effect on body temperatures and respiration rates. Journal of Dairy Science 89:3904-3914.

Smith T R, Chapa A, Willard S, Herndon Jr C, Williams RJ, Crouch J, Riley T, Pogue D (2006b) Evaporative tunnel cooling of dairy cows in the southeast. II: Impact on lactation performance. Journal of Dairy Science 89:3915-3923.

Suadsong S, Suwimonteerabutr J, Virakul P, Chanpongsang S, Kunavongkrit A (2008) Effect of Improved Cooling System on Reproduction and Lactation in Dairy Cows under Tropical Conditions. Asian-Australasian Journal of Animal Science 21:555560 .

Wang X, Zhang G, Choi CY (2018) Effect of airflow speed and direction on convective heat transfer of standing and reclining cows. Biosystems Engineering 167: 87-98.

West JW (2003) Effects of heat-stress on production in dairy cattle. Journal of Dairy Science 86:2131-2144.

Yani A, Purwanto BP (2006) Pengaruh iklim mikro terhadap respons fisiologis sapi peranakan fries holland dan modifikasi lingkungan untuk meningkatkan produktivitasnya. Media Peternakan 29:35-46.

Yousef, MK (1985) Stress physiology of livestock: thermoneutral zone. CRC Press Inc., Florida, pp 68-69. 